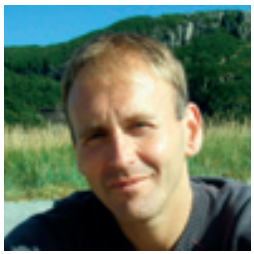

\title{
En smittsom praksis
}

\section{Selv om mange opplever selvskading som uforståelig, bisart eller avskyelig, har mitt fokus alltid vært å forstå fenomenet ut fra normalpsykologi.}

Da jeg for noen år siden begynte å skrive det som ble den første læreboken om selvskading på norsk, var det naturlig for meg å starte med mine pasienters beskrivelser av hvorfor de skadet seg. Og de opplevde å ha mange gode grunner. Så mange og så godt beskrevet at jeg etter hvert begynte å bli redd for at jeg var i ferd med å skrive en reklamebok om selvskading. Jeg skal ikke her referere beskrivelsene, men bare konstatere at selvskading er effektivt. På kort sikt. Og når du ikke vet hva annet du kan gjøre. De fleste som skader seg vet at det er ulemper med selvskading, og at det ikke er effektivt på lang sikt. Men de overmannes av et intenst negativt ubehag samtidig med en opplevelse av at selvskading er det eneste botemidlet som kan gi umiddelbar lindrende effekt.

Mange beskriver første gang de oppdaget dette «botemidlet» i ekstatiske ordelag, nærmest med religiøs glød. Eller med en glød som når en rusmisbruker forteller om sine snarvisitter $\mathrm{i}$ «rushimmelen». En pasient fortalte meg for eksempel: «Jeg hadde hatt den ekle følelsen såå lenge, men hadde ingen lindring før jeg lærte å stikke meg i låret med en korktavlestift. For første gang fant jeg noe som virket, og jeg gråt av smerte og glede.»

Det er erkjennelsen av at de som skader seg faktisk opplever fordeler med skadingen som har fått de nye kunnskapsbaserte psykoterapiene til å redefinere målet med behandling. Dialektisk atferdsterapi (DBT) og mentaliseringsbasert terapi (MBT) har begge som fokus at selvskading er pasientens «løsning» på å miste kontroll over sin affektregulering. Målet i begge behandlingsformene er derfor å hjelpe pasienten til å unngå eller redusere intensiteten i overveldende negative affekter, slik at pasienten ikke behøver å skade seg. Satt på spissen: isteden for å si at pasienten må slutte å skade seg, sier man at målet er å hjelpe han/henne til ikke å få behov for å skade seg. Veien dit går gjennom å lære å gjenkjenne og beherske egne følelsesog tankemønster, ved å sjeldnere feiltolke andres intensjoner og ved å løse indre og ytre konflikter på andre måter enn ved å skade seg.

Men den destruktive gløden virker skremmende på andre. Foreldre og terapeuter bekymrer seg for at gløden kan friste andre til å begynne med det. Og det er dokumentasjon på at selvskading «smitter». Flere undersøkelser viser at sannsynligheten er større for at en ungdom skader seg dersom han/hun kjenner noen andre som gjør det.

Hvorfor det er slik? Om det har man lite sikker viten. Men igjen anbefaler jeg det normalpsykologiske perspektivet. Jenta jeg siterte ovenfor oppdaget selvskading gjennom å avsløre at en venninne gjorde det. I motsetning til hva mange tror, forsøker faktisk den største gruppen av de som skader seg å gjøre det i skjul. Det bør ikke være en overraskelse, ettersom skam er den sentrale affekten i forkant og etterkant av selvskading. Skam, og atferd assosiert med skam, forsøkes å skjules. Men klinisk praksis og undersøkelser viser at mange av vennene vet om skadingen, enten fordi de har avslørt det eller blitt det betrodd av den som skader seg. Å dele hemmeligheter er en naturlig del av det å være barn og ungdom. Hemmeligheter er nærmest å regne som en valuta i den alderen. Du får en av meg, jeg får en av deg, og begge føler at forholdet blir sterkere av det. Å dele en hemmelighet om selvskading viser både at har tillit til den andre, og det gir en fortrolig atmosfære til å forklare hva det er med selvskading som oppveier ulempene. Dette er noe vi kjenner både fra annen problematferd som bulimi og rus. Men ikke minst vet vi at slik kommunikasjon er en del av den naturlige utviklingen, og at mye god kunnskap og ferdigheter læres på denne måten.

De nye kunnskapsbaserte behandlingsformene mot selvskading har vist at det finnes effektiv hjelp, men det er også interessant at behandlingene ikke nødvendigvis er så revolusjonære i innhold. De har klare likhetstrekk med annen kjent effektiv behandling mot andre lidelser som bulimi, rusmisbruk og psykotisk aggresjon. $\mathrm{Og}$ behandlingen tar utgangspunkt i bedre regulering av følelser som vi alle kan kjenne oss igjen i som skam, sinne og hjelpesløshet.

Jeg tror det er et tegn på modning i fagfeltet at normalpsykologi og psykopatologi finner sammen igjen, og det gir håp at ulike behandlingsformer finner hverandre i den samme forståelsen av et så vanskelig forståelig fenomen som selvskading er.

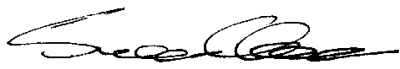

I neste nummer:
Tema: Selvskading

Vektnedgang hos nyfødte

Hemokromatose
Forekomst av litiumbruk

Bakteriell meningitt

Forskning på diaré 